\title{
Socio Economic Factors Causing Rapid Peatlands Degradation in South Sumatra
}

\author{
Elisa Wildayana ${ }^{1, *}$, M. Edi Armanto ${ }^{1}$, Imron Zahri $^{1}$, Dessy Adriani $^{1}$ and Bella Syakina ${ }^{1}$ \\ ${ }^{1,}$ Faculty of Agriculture, Universitas Sriwijaya, South Sumatra, Indonesia \\ *Corresponding Author: ewildayana@ unsri.ac.id
}

Article history

\begin{tabular}{lclc}
\hline Received & Received from reviced & Accepted & Available online \\
29 October 2018 & 07 December 2018 & 30 December 2018 & 11 January 2019 \\
\hline
\end{tabular}

\begin{abstract}
The research aimed to analyze the socio-economic determinant factors causing why peatlands in South Sumatra are rapidly degraded, thus it is threatening the existence of the human life support system. The research method was using an explorative and descriptive method by making the web portal of "Google search engine". Keywords were used for searching 'peatland', 'degradation' and/or 'socio-economic causes' in title and abstract. To analyze priority level of socio-economic aspects in contributing to peatlands degradation, thus an AHP analysis was conducted and interview with selected respondents. The research resulted that socio-economic determinant factors causing peatlands degradation are complex and integrated each other. Based on clustering the main sequence of causing peatlands degradation was performed by increasing population; increasing poverty; win-win approach; security of land ownership; and agricultural infrastructure and expansion respectively. Understanding this cluster with a comprehensive approach is needed to decide what factors play in the degradation of peatland, so that the policies made are precise and targeted. At this time the government requires to restore peatlands, so that peatlands can be preserved forever.
\end{abstract}

Keywords: degradation factors, restoration approach, socio-economic

Abstrak (Indonesian): Penelitian ini bertujuan untuk menganalisis faktor-faktor sosial ekonomi yang menyebabkan mengapa lahan gambut di Sumatera Selatan terdegradasi dengan cepat, sehingga mengancam keberadaan sistem pendukung kehidupan manusia. Metode penelitian menggunakan metode eksploratif dan deskriptif dengan membuat portal web "Google search engine". Kata kunci digunakan untuk mencari 'lahan gambut', 'degradasi' dan/atau 'penyebab sosial ekonomi' dalam judul dan abstrak. Untuk menganalisis tingkat prioritas aspek sosial ekonomi dalam berkontribusi terhadap degradasi lahan gambut, maka analisis AHP dilakukan dan wawancara dengan responden terpilih. Hasil penelitian menunjukkan bahwa faktor-faktor sosial ekonomi yang menyebabkan degradasi lahan gambut sangat kompleks dan terintegrasi satu sama lainnya. Berdasarkan pengelompokan urutan utama penyebab degradasi lahan gambut adalah peningkatan populasi; kemiskinan; pendekatan win-win; keamanan kepemilikan tanah; dan infrastruktur pertanian dan ekspansi masing-masing. Memahami kelompok ini dengan pendekatan komprehensif diperlukan untuk memutuskan faktor apa yang berperan dalam degradasi lahan gambut, sehingga kebijakan yang dibuat tepat sasaran. Pada saat ini pemerintah mengharuskan untuk memulihkan lahan gambut, agar lahan gambut dapat dilestarikan selamanya.

Kata kunci: faktor degradasi, pendekatan restorasi, sosial ekonomi,

\section{Introduction}

Naturally peatland ecosystem belongs to a stable ecosystem and tends to increase its peat thickness, but if the balance of its natural conditions is disturbed, then peatlands are easily degraded and lost altogether. Most peatlands are still covered by natural forest and habitats for various species of rare fauna and flora. More importantly, peatlands store large amounts of carbon (C). Peatlands also have a high water holding capacity, so that they serve as buffering zones of hydrology for the surrounding areas. Therefore, peatlands can be said to be a fragile ecosystem [1], [2], [3].

Peatlands spread across Indonesia with an acreage of around 21 Million ha, namely in Sumatra (6.24 Million ha), Kalimantan (5.07 Million ha), Papua (7.01
Millions ha), and the rest (about 2.68 Millions ha) spreading in other islands. Peatlands are used for timber commodities (teak, sengon) and plantations (rubber, oil palm, resin, fruits, coffee, chocolate, tea and others). Peatlands utilization is mostly done by land concession holders [4], [5].

The tropical peatland in February 2016 was only $8 \%$ of the total peatlands in the world, which reaching 400 million ha. It is estimated $60 \%$ of tropical peatlands located in Southeast Asia. During 19902000, around 1.5 million ha/year of peatlands in the tropical countries were disappeared, and about 0.80 million ha of peatlands were classified as heavily degraded. Indonesia has the largest peatlands among the tropical countries, which are about 21 million ha, spread mainly in Sumatra, Kalimantan and Papua. 
However, because peatland variability is very high in terms of peatland thickness, maturity or fertility, not all peatlands are worthy suitable for agricultural and plantation commodities. Of the 21 million ha peatlands on Indonesia, only about 6 million ha are feasible for agriculture and plantations [6], [7].

Rapid economic growth in the plantation has pushed high peatland conversion into plantation areas in South Sumatra. The peatland conversion rate tends to increase rapidly, while for non-peatland wetlands the increase is relatively slower. Productively limited peatlands causing agricultural extension leads to marginal peatland. Peatland conversion will disrupt all peatland ecosystem functions. Peatlands are one of the marginal wetlands chosen especially by large plantations, as it is relatively rare populated, so the possibility of peatland user conflict is relatively small [8], [9], [10].

The use of peatlands should be done carefully based on the results of a deep peatland characterization and peer review study. Peatlands developed for agriculture and plantation are only for fertile peatland with a peat thickness of less than $1 \mathrm{~m}$. Despite increasing research and understanding related to peatlands, the conditions of peatland management are still minimal compared to temperate and the boreal peatlands found in Northern Russia, Europe and Canada. However, now one of the last available lands for agricultural development is peatlands. The peatland ecosystem is very important in the downstream hydrology system of a watershed because it is able to absorb water up to 13 times its weight. In addition, peatlands have also a huge reservoir of carbon both above and below the soil surface [11], [12], [13].

Forest and land fires in Indonesia are almost occurring every year where, on a large scale, since 1982/83 around almost 1.00 million ha of peatlands in Sumatra have been destroyed. Since then peatland wildfires have continued with increasingly narrow time intervals from year to year. Around 95\% of wildfire incident is always triggered by early burning in human activities. One of the impacts of economic losses attracting the attention of all people was due to forest wildfires and peatlands of 1997/1998, it was estimated at 9.3 billion US dollars. The wildfires have caused peatland burning of about 9.8 million ha spread over Kalimantan, Sumatra, Java, Sulawesi and Papua. Some of the wildfires occurred in peatlands. Wildfires in peatlands have different characteristics compared with other fires, because they can produce canopy and surface fire and wildfires under peatlands that produce thick smoke, so much harm to various parties [14], [15], [16].

In the natural forest state, peatlands are acting as a carbon blocker contributing to the reduction of greenhouse gases in the atmosphere, although the milling process runs very slowly as high as 0-3 $\mathrm{mm} / \mathrm{year}$ of peatland, equivalent to $0-5.37$ ton $\mathrm{CO}_{2} /$ ha/year. When peatlands are over drained, the carbon stored in the peatlands easily oxidizes to $\mathrm{CO}_{2}$ gas (one of the most important greenhouse gases). Peatlands are also susceptible to subsidence if peatlands are cultivated. Therefore, careful planning is required when converting peatlands. Planning should refer to the results of in-depth study of local peatland characteristics and their impact if peatlands will be converted [17], [18], [19].

Various efforts to resolve the peatland fire problems have been done, but they have not shown optimal results and peatland fires continue to occur repeatedly until present. In relation to the above problems, this study aims to analyze the socioeconomic determinant factors causing why peatlands in South Sumatra are rapidly degraded?

\section{Material and Methods}

The research location is sited in Ogan Komering Ilir (OKI) district, South Sumatra Indonesia (Figure 1). The research method was using an explorative and descriptive method by making the web portal of "Google search engine". Keywords were used for searching 'peatland', 'degradation' and/or 'socioeconomic causes' in title and abstract. Each journal paper fulfill all criteria (keywords) called as 'hits'. All "hits" are processed and analyzed according to predefined variables and categories estimated to provide a measurable relationship to the current contribution of peatland degradation. The results of this web portal have succeeded in filtering out 201 publications appearing in four reputable journals from July 2014 to October 2018.

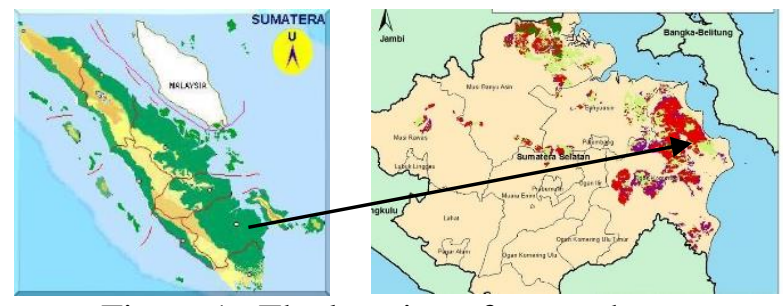

Figure 1. The location of research area

The explorative method aims to get ideas and views on peatland degradation that occurred or to know the condition of a particular degradation due to the use of peatlands. The descriptive method aims to determine parameters of peatland degradation, the frequency of the occurrence of something with other relationship. Data were digitally collected, processed and evaluated with the SPSS Program and the results are displayed in the form of tables, graphs, descriptions and narratives. Methods of searching and filtering journal paper presented in the form of flowchart diagram are presented in Figure 2. 


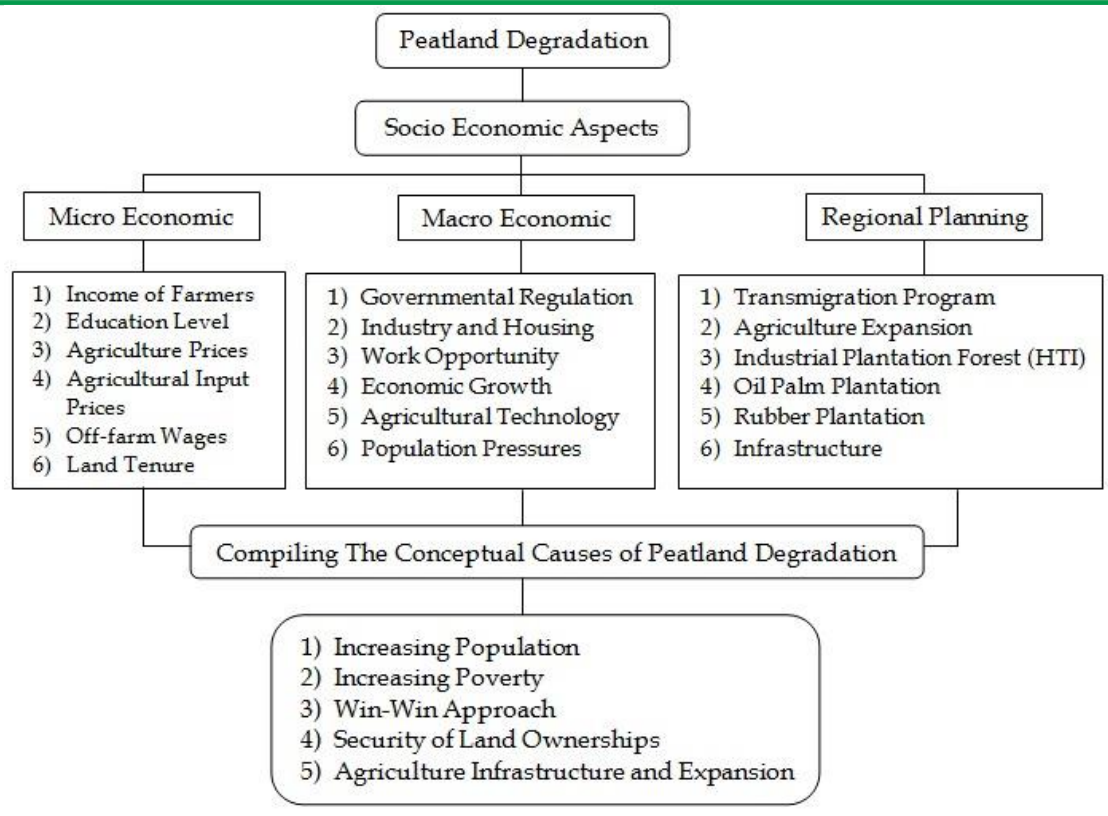

Figure 2. Conceptual causes of peatland degradation

To analyze priority level of socio-economic aspects in contributing to peatlands degradation, thus an AHP analysis was conducted. Based on the AHP results, it can be sorted out what components contribute the most influence on peatlands degradation. Finally interviews with respondents were carried out in order to get some opinions of local farmers.

\section{Results and Discussion}

The results and discussion of this paper emphasize the history of human intervention on peatland in the period of before 1960 to 2000; after 2000 to present. Then it was followed by analyzing micro and macroeconomic aspects, as well as regional planning analysis causing peatland degradation. Finally it was discussed about compiling the conceptual causes of peatland degradation.

\subsection{Developing Peatland Before 1960 to 2000}

Developing peatlands before 1960 to 2000 can be grouped in four episodes, namely periods of before $1960 ; 1960-1980 ; 1980-1980$, and 1990-2000. The grouping of this period is based on intensive human intervention on peatlands, without adequate knowledge and technology. However, peatland recovery capacity is higher than human intervention, so peatland degradation may still be overcome by local knowledge and technology (Table 1).

Table 1. Developing peatland before 1970 to 2000 in the research area*/

\begin{tabular}{|c|c|c|}
\hline Periods & Main activity & Targeted components \\
\hline \multirow[t]{2}{*}{ Before 1960} & Fishing and hunting wild animals & $\begin{array}{l}\text { Freshwater fishes, deer, pigs, birds, weasel, mouse, deers, forest goats, } \\
\text { rabbits and others }\end{array}$ \\
\hline & Harvesting non-forest timbers & $\begin{array}{l}\text { Honey, fuel woods, fodders, latex, fern, bamboo, mushrooms, spices, } \\
\text { webbing strap, nipah }\end{array}$ \\
\hline \multirow[t]{5}{*}{$1960-1980$} & $\begin{array}{l}\text { Cultivating peatlands by Buginese } \\
\text { and Banjarnese }\end{array}$ & Coconut, rice, vegetable, fruits \\
\hline & Harvesting forest timbers & Ramin, red meranti, rattan, jelutung, durian burung, kempas, red palm \\
\hline & Sonor system by local farmers & Food crops, vegetable, horticulture, tuber crops, medical plants, spices \\
\hline & Fishing and hunting wild animals & Freshwater fishes, deer, pigs, birds, mouse deers, elephants, tiger \\
\hline & Harvesting forest timbers & Ramin, red meranti, rattan, jelutung, teak, rengas \\
\hline \multirow[t]{5}{*}{$1980-1990$} & $\begin{array}{l}\text { Planning to utilize peatland by the } \\
\text { Government }\end{array}$ & Transmigration program, agriculture revitalization, land expansion \\
\hline & Sonor system by local farmers & Food crops, vegetable, horticulture, tuber crops, spices, medical plants \\
\hline & Land clearing by burning & Land conversion to plantation \\
\hline & Illegal logging & Red meranti, rattan, jelutung, beringin, rasau \\
\hline & Sawmill & Red meranti, rattan, jelutung, beringin, rasau \\
\hline \multirow[t]{3}{*}{$1990-2000$} & Sonor system by local farmers & Food crops, vegetable, horticulture, tuber crops, spices, medical plants \\
\hline & Land clearing by burning & Land conversion to plantation \\
\hline & Illegal logging & Red meranti, rattan, jelutung, beringin, rasau \\
\hline
\end{tabular}

Note : * It is based on secondary data and may be changed temporally

Source: Field survey results analysis (2018). 
1) The Period of Before 1960

Peatlands have been intervened by local communities since 1900s to meet their subsistence only, such as the needs for wood and bamboo (for their houses and agricultural equipment), as well as the fulfillment of food needs (e.g. fish, honey, wild meat, spices and traditional medicine). In this period peatland concessions have not been introduced to the community, so peatlands are still mentioned as a public good and anyone is allowed to harvest. Planting activities have not been done by local communities. They only do the harvesting in the form of fishing, hunting wild animals and harvesting non-forest timbers. Government intervention has not existed in this period and peatland was still a naturally protected area.

2) The Period of $1960-1980$

In 1960-1980 peatland began to get harvesting pressure on peatland forest and traditional planting has been started. This planting activity was first performed by Bugisnese and Banjarese tribes who migrated to South Sumatra by sailing through river channels on the seashore, then they settled and cultivated. In 1970 the local community harvested peatlands to meet their daily needs, such as fishing and hunting wild animals, such as deer, goat, pigs, deer, buffalo, and rabbits for food.

The government began to develop timber trade for export as international trade and tropical timber trees began to take place between countries. Various highselling timbers were harvested, including ramin (Gonystylus bancanus), red meranti (Shorea spp), teak (Tectona grandis), rattan (Calamus axillaris), jelutung (Dyera costulata), bird durian (Durio zibethinus), kempas (Koompassia malaccensis), and red palm (Cyrtostachys renda). However, because the efforts of harvesting of forest plants in peatland required hard work because of the limited facilities and infrastructure causing exploitative to peatland forest was still very low, so that the authenticity of peatland forest was still maintained.

In this period peatland concessions have been introduced to the local community, so peatlands are no longer a public good and only concessions are allowed to harvest, and planting activities also involve local communities. In addition, local farmers started to cultivate sonor system on peatlands; they started planting food crops, vegetable, horticulture, tuber crops, medical plants, spices and others. The sonor system is a kind of shifting cultivation and farmers moved from one place to other place. The fallow period of the sonor system was in the range of 5-10 years, meaning that after 5-10 years, the local people would return to the first location where they have done the sonor system. In addition to the sonor system, farmers also continue to hunt wild animals for selfconsumption. Non-timber forest products were also Vol. 3 No. 3, 87-95 harvested to meet the needs of life, such as honey, firewood, fodders, latex, mosses, ferns, bamboo, mushrooms, spices, webbing, nipah and others.

3) The Period of 1980-1990

In 1980-1990 peatlands experienced many developments from the government program both for the granting of forest concessions and transmigration programs. The transmigration programs were conducted with the aimed to improve good living of poor people; population equity; managing human powers from rich human resource areas to less human resource areas; strengthening national security; promoting national unity; opening up economic potentials; and creating jobs opportunity. Agriculture revitalization was also done by the government to improve the welfare of farmers and fishermen as well as to contribute to the national income growth, export of non-oil components, and giving work opportunity for national labor.

In addition, the activities of the sonor system is still continued by the local community, but the fallow period is getting shorter (each 3-5 years). Main commodities cultivated in this sonor system is rice (Oryza sativa), food crops, vegetables, horticulture, tubers, spices and medicinal plants. However, to do farming with the sonor system is accompanied also by the opening of peatland activity by burning. Prior to peatland conversion into plantations, peatland burning can certainly have a negative impact on peatland itself. Planting trees that have a selling value are also kept by farmers as an additional income for them.

Negative impact of the sonor system after postharvest period left is that peatlands are abandoned and in fallow forms, and then they cleared other peatlands by burning. The abandoned peatland is susceptible to fires, especially during the dry season. In addition, the community also performs illegal logging activities on peatlands. The harvested items taken by the community in illegal logging were red meranti, rattan, jelutung, beringin and rasau. Both peatland burning and illegal logging activities have a negative impact on peatlands. The peatland ability to absorb water or to control water will decrease, besides illegal logging can also lead to decrease available biodiversity on peatlands.

In this period many sawmills were built to process wood timbers into boards, wood sizes ready for export. The number of sawmills was increasing to meet the demand for wood processing from illegal logging, so that sawmills appeared anywhere on peatlands.

4) The Period of 1990-2000

In 1990-2000 peatland experienced much progress from government program activities to grant forest concessions and to prepare land clearing for plantations and HTI on a large scale. The opening of peatland is done by burning forest and peatland area that has been harvested timber a second time. Sonor http://dx.doi.org/10.22135/sje.2018.3.3.87-95 90 
system was still continued by local people still with the fallow period was shorter (each 2-3 years) and illegal logging was still also carried out by local community. However, planting trees having a selling value are also kept by farmers as an additional income for them. In this period many sawmill have started collapsed due to lack of raw materials to be processed. The demand for wood processing on sawmills was declining, except for wood processing from illegal logging, thus many sawmills were totally closed.

\subsection{Developing Peatland after 2000 to Present}

Developing peatlands after 2000 to present can be grouped in three episodes, namely periods of 2000-
2010; 2010-2015; and after 2015. This grouping is based on information disclosure, technology and intensive intervention of scientists and researchers on peatlands (Table 2).

\section{1) The Period of 2000-2010}

This period was characterized by infrastructure development; access opening for plantation building, such as oil palm and rubbers and acacia plants (HTI, industrial plantation forest) that have high economic values. Small plantation activities are carried out by local farmers in peatlands with still relatively small and traditional technology.

Table 2. Developing peatland after 2000 to present in the research area

\begin{tabular}{cll}
\hline Periods & \multicolumn{1}{c}{ Main activity } & \multicolumn{1}{c}{ Targeted components } \\
\hline $2000-2010$ & Small scale of plantation & Oil palm, rubber, acacia. \\
& Industry and Settlement & Palm oil mills, housings \\
& Local housing & Traditional houses \\
& Infrastructure development & $\begin{array}{l}\text { Roads, bridges, watergates, drainage channels, irrigation, reservoir, } \\
\text { embankment, dams }\end{array}$ \\
& Population pressure & Migration to peatland \\
\hline $2010-2015$ & Large scale of plantation & Oil palm, rubber, acacia \\
& Industry and settlement & Palm oil mills, housings \\
& Local housing & Traditional houses, residential areas \\
Infrastructure development & Roads, bridges, watergates, drainage channels, irrigation, market \\
& Infrastructure development & Roads, bridges, watergates, drainage channels, irrigation, terminal, market, \\
& & transportation \\
\hline & Restoration & Establishing restoration body (BRG), ramin, red meranti, rattan, jelutung, \\
& & gemor, teaks \\
& Illegal logging prevention & Working groups for illegal logging prevention, capacity building (reward- \\
& & punishment) \\
& Forest and land fire prevention & Working groups for wildfire prevention \\
& Society empowering & Purun, pineapples, aloe vera, sago, jelutung. \\
& Economic development & Income per capita, inflation, technology, information and communication, \\
& Cilviculture & skill labor \\
& Ramin, red meranti, rattan, jelutung, gemor, teaks
\end{tabular}

Note : * It is based on secondary data and may be changed temporally

Source: Field survey results analysis (2018).

Large plantations are carried out by both government and private companies and development of plantation business is significantly increasing as evidenced by the increasing number of peatlands converted into oil palm, rubber and acacia. The plantations are able to increase local income surrounding plantation business areas.

The development was also accompanied by the making settlements, and constructing housing for the community. Housing built also varies, ranging from traditional housing to modern housing. Given the various developments, it gives a lot of development in order to provide easy access in performing various activities. This is the underlying infrastructure development, such as roads, bridges, water gates, drainage channels, irrigation, reservoirs and dikes. The construction of these infrastructures attracts people from other regions to try their luck in the areas. So there is migration to peatlands. Various developments that occur in peatland is interrelated, thus affecting each other and of course give both positive and negative impact on peatlands.

2) The Period of 2010-2015

In this period, development of plantations, agriculture and HTI in peatland was increasingly widespread, especially for oil palm (Elais guenensis), rubber (Hevea brasiliensis) and acacia (Acacia crassicarpa). The development has stimulated the establishment of the construction of large-scale infrastructure, followed by the development of processing industries, such as palm oil processing mills, and development of residential areas of the population. This development occurs because the price of the plantation products is quite high, thus attracting 
the public interest to obtain higher income. The development of the processing industry was able to increase regional income and increase regional economic growth.

3) The Period of After 2015

Increasing population growth causes an increasing need for facilities and infrastructure, including infrastructures to support life. In this period developing peatlands was characterized by peatland degradation resulting in the restoration activities of both government and community with various reforestation programs. Hence the degradation that led to restoration and reforestation efforts.

After 2015 infrastructure development is a top priority in regional development, such as roads, bridges, laying bridges, toll roads, terminals, transportation and any others? The rapid development of infrastructure led to a decrease in available peatlands, so that restoration efforts were intensively undertaken by an agency known as BRG (Peatland Restoration Agency). The restoration applied by BRG is carried out by re-greening and replanting the natural peatland vegetation, such as ramin, red meranti, teak, jelutung and others in order to prevent peatland degradation.

Still, illegal logging is increasingly prevalent against peatland encouraging illegal logging groups or institutions by implementing various programs as an effort to prevent illegal logging that could cause flooding. Peatland opening for sonor system or land clearing impacting peatland wildfires encourages people to grow paludiculture or flameproof plants, such as purun, pineapple, aloe vera and sago plant. This is a form of community empowerment in the effort to prevention of wildfires on peatlands. One of the efforts to reforest and conserve peatland forests is to apply the silvicultural system. Silvicultural system is a planned activity covering rejuvenation, maintenance and logging in order to preserve the forest products both timber and non timber. In addition, the commodity management is economically valuable in peatlands, which are also able to increase income of farmers having an impact on increasing economic growth.

\subsection{Micro Economic Aspects Causing Peatland Degradation}

Micro economic describes a narrow economic scope which includes economic activities undertaken by the local community for subsistence farmers. The micro economic aspects are directly affecting the degradation of peatlands. This means that when the activity is implemented, it will directly affect the state of degradation peatlands. Various aspects of microeconomics that directly affect the degradation of peatlands are summarized in Table 3.

Micro-economic actors are local people, especially local farmers; because the perpetrators of micro economic are a local community, then the condition is site-specific (different from one site to other sites). Not only as micro-economic actors are local people, but also the holder of peatlands management.

Table 3. Micro economic aspects causing peatland degradation

\begin{tabular}{|c|c|c|c|}
\hline \multirow{2}{*}{ Variable } & \multicolumn{2}{|c|}{ Effect of variable increase } & \multirow{2}{*}{ Comments } \\
\hline & Analytical & Field facts & \\
\hline $\begin{array}{l}\text { Income of } \\
\text { farmers }\end{array}$ & Indeterminate & Increase & $\begin{array}{l}\text { Increasing income of farmers is due to increased agricultural } \\
\text { activity in peatlands, such as the sonor system }\end{array}$ \\
\hline $\begin{array}{l}\text { Education } \\
\text { level }\end{array}$ & Reduce & Reduce & $\begin{array}{l}\text { Increasing knowledge and technology, society more aware and able } \\
\text { to do better environmental management. }\end{array}$ \\
\hline $\begin{array}{l}\text { Agricultural } \\
\text { prices }\end{array}$ & Increase & Increase & Encouraging farmers to be more active in farming activities \\
\hline $\begin{array}{l}\text { Agricultural } \\
\text { input prices }\end{array}$ & Indeterminate & Mixed & $\begin{array}{l}\text { Increasing the price of fertilizer can lead to a decrease in farmer } \\
\text { interest, but can also increase degradation as farmers burn the litter } \\
\text { of the plant to become fertilizer, thus damaging the layers in the } \\
\text { peatlands }\end{array}$ \\
\hline $\begin{array}{l}\text { Off-farm } \\
\text { wages }\end{array}$ & Reduce & Reduce & $\begin{array}{l}\text { Farmers do not have any more free time to do activities outside the } \\
\text { farm }\end{array}$ \\
\hline Land tenure & Improve & $\begin{array}{l}\text { A little bit } \\
\text { evidence }\end{array}$ & $\begin{array}{l}\text { Claiming the future land rents will offer farmers an extra income } \\
\text { for clearing the lands }\end{array}$ \\
\hline
\end{tabular}

Note : */ It is based on secondary data and may be changed temporally

Source: Field survey results analysis (2018).

\subsection{Macro Economic Aspects Causing Peatland Degradation}

The scope of macroeconomic includes activities in large scale, including the activities of industry and housing. Actors in macroeconomic is the central or national government that is equitable. This is because they make some regulations and policy rules to be implemented to all peatlands in Indonesia. The impact 
of macroeconomic on peatlands degradation is slow, but definitely influential. This means that when the activity is done, then the impact of degradation is little by little influenced (Table 4 ).

Table 4. Macroeconomic aspects causing peatland degradation

\begin{tabular}{llll}
\hline \multirow{2}{*}{ Variable } & \multicolumn{2}{c}{ Effect of variable increase } & \multicolumn{2}{c}{ Comments } \\
\cline { 2 - 3 } $\begin{array}{l}\text { Governmental } \\
\text { regulation }\end{array}$ & Reduce & Reduce & $\begin{array}{l}\text { Restrictions on areas opened through government regulations, i.e. } \\
\text { peat criteria for conservation areas }\end{array}$ \\
\hline $\begin{array}{l}\text { Industry and } \\
\text { housing }\end{array}$ & Increase & Increase & $\begin{array}{l}\text { Occurrence soil compaction due to the conversion of land to non- } \\
\text { agriculture }\end{array}$ \\
\hline Work opportunity & Reduce & Reduce & $\begin{array}{l}\text { Increasing employment opportunities in other sectors, decreasing the } \\
\text { desire to cultivate peatlands }\end{array}$ \\
\hline Economic growth & Indeterminate & Mixed & $\begin{array}{l}\text { Increasing income will improve demand of agricultural products and } \\
\text { market access, as well as increase off-farm works }\end{array}$ \\
\hline $\begin{array}{l}\text { Agricultural } \\
\text { technology }\end{array}$ & Indeterminate & Mixed & $\begin{array}{l}\text { Reducing the price of agricultural products, and increase wages for } \\
\text { farmers and suppress the bank interest (unless the change reduces the } \\
\text { intensity of work and/or capital) }\end{array}$ \\
\hline $\begin{array}{l}\text { Population } \\
\text { pressures }\end{array}$ & Improve & Improve & $\begin{array}{l}\text { Population density affects peatlands degradation, especially in rural } \\
\text { areas }\end{array}$ \\
\hline
\end{tabular}

Note : " It is based on secondary data and may be changed temporally

Source: Field survey results analysis (2018).

The more increasingly widespread macroeconomic activity is done, and then slowly affects the degradation of peatlands at the in situ level to national level and in the long term. The various macroeconomic aspects affecting peatlands degradation are governmental regulation; industry and housing; work opportunity; economic growth; agricultural technology; and population pressures. Some variables of macroeconomic affecting decision makers are so complex and there are a lot of indirect causal relationships.

\subsection{Regional Planning Components Causing Peatland Degradation}

It is a complex planning affecting degradation of peatlands because regional planning is a massive undertaking on peatlands, which is strongly related to macro-economic. Activities undertaken in regional planning is a regional development activity. The impact of regional planning on peatlands degradation depends on the spatial planning of regional areas (province, district and sub district). Often the development is not in accordance with the spatial allocation of the area, for example in peatlands with a depth of more than $3 \mathrm{~m}$, should be intended only as a protected area, not as an area of oil palm plantations. This causes the low productivity of oil palm plant and causing degradation of peatlands (Table 5).

Table 5. Regional planning factors causing peatland degradation

\begin{tabular}{|c|c|c|c|}
\hline \multirow{2}{*}{ Variable } & \multicolumn{2}{|c|}{ Effect of variable increase } & \multirow{2}{*}{ Comments } \\
\hline & Analytical & Field facts & \\
\hline $\begin{array}{l}\text { Transmigration } \\
\text { program }\end{array}$ & Increase & Increase & Land clearing for settlement and agricultural land \\
\hline $\begin{array}{l}\text { Agricultural } \\
\text { expansion }\end{array}$ & Increase & Increase & Agricultural developments lead to continuous land clearing \\
\hline $\begin{array}{l}\text { Industrial Plantation } \\
\text { Forest (HTI) }\end{array}$ & Intermediate & Mixed & $\begin{array}{l}\text { HTI reduces degradation through replanting systems, but increases } \\
\text { degradation with monoculture forest (acacia) that increases greenhouse } \\
\text { gas emissions }\end{array}$ \\
\hline Oil palm plantation & Increase & Increase & $\begin{array}{l}\text { Increased emissions of carbon dioxide gases as well as decreased high } \\
\text { groundwater levels due to over drainage }\end{array}$ \\
\hline Rubber plantation & Increase & Increase & $\begin{array}{l}\text { Peatland conversion to rubber plantation due to dry soil conditions and } \\
\text { high latex prices }\end{array}$ \\
\hline Road accessibility & Improve & Improve & Existence of roads will give everyone access to harvest the peatlands \\
\hline
\end{tabular}

Note : */ It is based on secondary data and may be changed temporally

Source: Field survey results analysis (2018). 
The rules concerning regional planning are made by the central government and implemented by the local government, namely by regional regulations (Perda). Both local communities and investors often violate existing spatial arrangements, withdraw again in case of spatial violations, then the existing spatial will be revised. This is clearly contrary to the basic concept of layout, where each development has to follow the spatial planning. The reality in the field, it turns out that the spatial planning follows any kind of development.

Three aspects mentioned above (i.e. micro economic; macroeconomic; and regional planning) affecting the degradation of peatlands are complex and integrated. The impact implied increases degradation and also decreases degradation in peatlands depending on site specific and peatlands conditions.

Table 6. Compiling the conceptual causes of peatland degradation

\begin{tabular}{lc}
\hline $\begin{array}{c}\text { Components of the conceptual } \\
\text { causes }\end{array}$ & $\begin{array}{c}\text { Peatland degradation } \\
\text { contribution }(\%)\end{array}$ \\
\hline Increasing population & 26.89 \\
Increasing poverty & 24.21 \\
Win-win approach & 19.15 \\
Security of land ownership & 15.27 \\
$\begin{array}{l}\text { Agriculture infrastructure and } \\
\text { expansion }\end{array}$ & 14.48 \\
\hline Total & 100.00 \\
\hline
\end{tabular}

Note : */ It is based on secondary data and may be changed temporally

Source: Field survey results analysis (2018).

Increasing population was found as a determinant factor affecting the degradation of peatlands contributing around $26.89 \%$, whereas increasing poverty contributed about $24.21 \%$ and followed by win-win approach (19.15\%), security of land ownership (15.27\%) and the lowest was given by agriculture infrastructure and expansion about $14.48 \%$ respectively.

Increasing population is connected the need of settlement and farming expansion in order to fulfill their foods and wood materials for housing, while the poverty factor causing the local community is relatively difficult to get access for employment, thus they cultivated peatlands as their main source of livelihood. Win-win approach is due to social jealous between local community and large private companies which utilized peatlands for oil palm plantation and HTI, thus they did sonor system for having foods. Most social jealous stimulated wildfires, which totally degraded peatlands.

Furthermore, the security of land ownerships conducts any activity on peatlands in order to show to other people that the peatlands belong to them. Sometime their activity is not purposed to produce agricultural products, but just to mark the lands which

Vol. 3 No. 3, 87-95

\subsection{Compiling the Conceptual Causes of Peatland Degradation}

Compilation of the conceptual causes of peatland degradation states clustering of microeconomics, macroeconomics and regional planning. This clustering is indispensable because each aspect of all components (microeconomics, macroeconomic and regional planning) influences in an integrated manner and related to each other. This compiling aims to simplify understanding the socio-economic aspects of peatland degradation. Based on survey results in the field by using AHP approach and interview results with respondents, the main sequence causing peatlands degradation was performed by increasing population; increasing poverty; win-win approach; security of land ownership; and agricultural infrastructure and expansion respectively (Table 6). owned by them. Their land ownership was often stated without any evidence of ownership, such as land certificates. Beside that some people (determined as land speculators) buy land, just to hold the lands. Furthermore the lands would be offered to investors, who will make plantation or HTI and they sold the lands with high prices.

Finally, the agriculture infrastructure and expansion was created by Government program to develop regional planning. This activity can lead to peatland degradation, in forms of soil compactions, peat subsidence, reducing water-holding capacity of peatlands. The easiest way before infrastructure built was to burn the peatlands for land clearing. This can certainly lead to peatland degradation.

\section{Conclusion}

Peatlands were developed in line with the economic development and government policies. Therefore, the government is responsible for all made policies on the use of peatlands. Government policies are inadequate to the functions and services of peatland ecosystem, so that peatland degradation was ostensibly planned and programmed by the government in a hierarchical and structured way by relying on the development of the economic development of rural communities. At this time the government requires to restore peatlands, so that peatlands can be preserved forever.

\section{Acknowledgement}

This paper is based on a mutli-year project funded through the "Penelitian Unggulan Profesi Dosen" Sriwijaya University. In this occasion, the authors would like to thank the entire staffs of the Faculty of Agriculture, Sriwijaya University, for the guidance and support offered for project work both in the field and in the laboratory, and to all students and local people who have reached out for this research. Authors recognizes 
and owes all the contribution of experts in providing comments and constructive feedback. Authors also appreciates the very useful contribution of coordination and all facilitation provided by the project. Authors is also grateful for the contributions and valuable comments from the supporting staffs from the initial draft to the completion of this paper. Finally we also thank the anonymous reviewers of the journal editors for their invaluable comments and inputs for the perfection of this paper.

\section{References}

[1] Aswandi, R. Sadono, H. Supriyo, Hartono. "Tropical Peat Swamp Management Options: A Case Study Using System Dynamic in Southern Aceh". JMHT Vol 21(3); 172-183. 2015.

[2] D. Astiani. "Tropical Peatland Tree-Species Diversity Altered by Forest Degradation". Biodiversitas. Vol 17(1); 102-109. 2016.

[3] E. Wildayana, M.E. Armanto. "Dynamics of Landuse Changes and General Perception of Farmers on South Sumatra Wetlands". Bulgarian Journal of Agricultural Science, Vol 24(2); 180188. 2018.

[4] E. Wildayana, M.E. Armanto, M.S. Imanudin, H. Junedi. "Characterizing and Analyzing Sonor System in Peatlands". Journal of Wetlands Environmental Managements, Vol 5(2); 6-13. 2017.

[5] J.P. Krueger, Leifeld, J., Alewell, C. "Degradation Changes Stable Carbon Isotope Depth Profiles in Palsa Peatlands". Biogeosciences, Vol 11; 3369-3380. 2014.

[6] M.E. Armanto, E. Wildayana, M.S. Imanudin, H. Junedi, M. Zuhdi. "Selected Properties of Peat Degradation on Different Land Uses and the Sustainable Management". Journal of Wetlands Environmental Managements, Vol 5(2); 14-22. 2017.

[7] T. Yu. Minayeva, O.M. Bragg, A.A. Sirin. "Towards Ecosystem-Based Restoration of Peatland Biodiversity". Mires and Peat, Vol 19(1); 1-36. 2017.

[8] B. Glina, A., Bogacz, M., Gulyás, B., Zawieja, P., Gajewski, Z. Kaczmarek. "Effect of Long-Term Forestry Drainage on the Current State of Peatland Soils: A Case Study from the Central Sudetes, SW Poland". Mires and Peat, Vol 18(21); 1-11. 2016.

[9] D. Adriani, I. Zahri, E. Wildayana, Maryadi, M. Hamzah and Yulius. "Farmer's Welfare in
Telang's Integrated Independent City: Lesson Learned from Migrant and Local Farmers in Tidal Land, South Sumatra". IOP Conf. Series: Earth and Environmental Science, Vol 122; 1-7. 2018.

[10] W. Giesen. "Utilizing Non-Timber Forest Produscts to Conserve Indonesia's Peat Swamp Forests and Reduce Carbon Emission". Journal of Indonesian Natural History, Vol 3(2); 10-19. 2015.

[11] E. Wildayana. "Formulating Rice Fields Conversion Control to Oil Palm Plantations in Tidal Wetlands of South Sumatra, Indonesia". Journal of Wetlands Environmental Managements. Vol 3(2); 72-78. 2015.

[12] E. Wildayana. "Challenging Constraints of Livelihoods for Farmers on the South Sumatra Peatlands, Indonesia". Bulgarian Journal of Agricultural Science, Vol 23(6); 894-905. 2017.

[13] H. Junedi, M.E. Armanto, M.S. Imanudin. "Changes to Some Physical Properties due to Conversion of Secondary Forest of Peat into Oil Palm Plantation". Sriwijaya Journal of Environment. Vol 2(3); 76-80. 2017.

[14] I. Zahri, D. Adriani, E. Wildayana, Sabaruddin, and M.U. Harun. "Comparing Rice Farming Appearance of Different Agroecosystem in South Sumatra, Indonesia". Bulgarian Journal of Agricultural Science, Vol 24(2); 189-198. 2018.

[15] J. Miettinen, Hooijer. A., Vernimmen. R., Liew. S. C., Page. S.E. "From Carbon Sink to Carbon Source: Extensive Peat Oxidation in Insular Southeast Asia Since 1990”. Environ. Res. Lett. Vol 12; 1-10. 2017.

[16] J.P. Krueger, Leifeld, J., Glatzel, S., Szidat, S., Alewell, C. "Biogeochemical Indicators of Peatland Degradation - A Case Study of a Temperate Bog in Northern Germany". Biogeosciences, Vol 12(10); 2861-2871. 2015.

[17] M.S. Imanudin, E. Wildayana, M.E. Armanto. "Option for Land and Water Management to Prevent Fire in Peat Land Areas of Sumatera Indonesia". Journal of Wetlands Environmental Managements, Vol 6(1); 12-26. 2018.

[18] E. Wildayana, M.E. Armanto. "Formulating Popular Policies for Peat Restoration Based on Livelihoods of Local Farmers". Journal of Sustainable Development, Vol 11(3); 85-95. 2018.

[19] M. Könönen, J. Jauhiainen, R. Laiho, K. Kusin and H. Vasander. "Physical and Chemical Properties of Tropical Peat under Stabilized Land Uses". Mires and Peat, Vol 16(8); 1-13. 2015. 